\title{
Premises and features of building elements of artificial intellect in systems of on-line control over agrarian and industrial complex
}

\author{
V. Myronenko, \\ Doctor of Technical Sciences \\ National Scientific Center "Institute of Mechanization and Electrification of Agriculture" NAAS
}

The purpose. To formalize main positions and to specify perspectives of development of intellectual automaticcontrol systems over production processes of farming industry. Methods. Analysis of opportunities of heightening efficiency of agroindustrial production and problem of building artificial intellect for control of engineering systems. Synthesis of general structure of neuro-similar net of integral system of on-line control over agricultural production processes and principles of formation of database for its provision. Results. The structure of intellectual component of automatic-control system over the production process, architecture of engineering neuro-similar net is specified. Principles of construction of algorithm of automatic formation of control action of production process on the basis of restoring knowledge base are generalized. Conclusions. Basic gain in yield of agricultural products from unit of cultivated area is possible at heading new intellectual technologies of production. The level of artificial intellect in guidance systems over technological processes of farming industry can be limited by use of theories of evaluations and logic. The key job of building intellectual guidance systems of production processes of farming industry nowadays is formalization of knowledge base.

Key words: technological operations, system of integrated control, elements of artificial intelligence, knowledge base.

Problem. Further substantial increase of efficiency of agricultural production is only possible at the expense of operational and purposeful quality management of execution technological operations of cultivation of alive facilities - soil, plants, animals. In this regard further development technical providing for agricultural manufacturing will be based on the creation of new technological equipment, the main feature of which lies in automatically change operating modes of working bodies on the basis of operational information for achievement of optimal phase condition of the object that the is being processed. It is obvious that simple substitution of the human expert on linear systems of automatic control respective working bodies, in this case, already has inadequate - are necessary elements of artificial intelligence for the cultivation of large volumes of diverse information and better decision making.

\section{Analysis of the latest research and publications.}

The technical essence of the new level of automation is to move from the reactive a principle of work automatic systems for the deviation of individual parameters for complex multi management, with the active involvement of object information from cultivation, environmental, technical and specialized databases.

There are different models of formalization of human intelligence. [1] One of the most classic can be considered a model which identical to the processes adapt of biological organisms to their environment. These programs do not resolve the problem by means of logical reasoning but create system solutions, which compete with each other for get the best results at each specified stage.

Most of the scientists [2,3,4] inclined to believe that the artificial intelligence - is algorithm of actions a highly organized matter, which is endowed personality and ability to receive, data storage and processing information, generate new knowledge and independent decision making relative to set her developer objectives and goals. If we talk about artificial personality, in its structure have to be of substructures of solving problems objective (Law), subjective (feeling) and irrational (faith) content. 
The purpose of the research. Formalize the basic position and determine the prospects of development of intelligent automatic control by technological processes agricultural production.

Results of research.

Artificial intelligence, conditionally, can be represented system of multi-level theories. Basic level - a theory of computing (neural networks), which is characteristic of self-improvement - perception of the information, physical interaction with the environment. The next level - the theory of logic - deduction, induction, support for truth, thinking patterns, and more. The final level - the theory of psychology understanding of social processes.

When creating real artificial intelligence systems important to correctly evaluate limits of our current necessities, opportunities and achievements. Analysis of the development automation control the processes of systems in advanced branches of industry and technology reveals that these systems come practically to the level of robotic systems, based on the first two levels theory of artificial intelligence. In general form is complex has a structure which is represented in Figure 1.

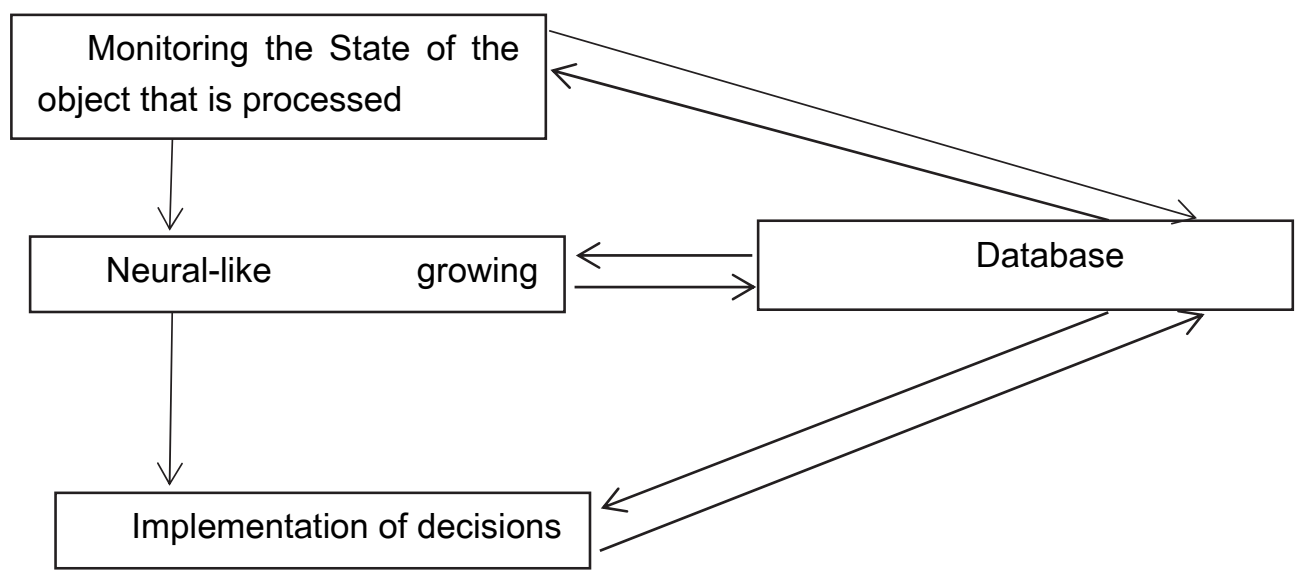

Fig. 1. Structure of the intellectual component system of automatic controlling the technological process

Technological processes of agricultural production as managed objects that in need of constant monitoring of their parameters and characteristics. The complexity of monitoring depends on the level of automation of receiving, processing, storage and documentation of operative information about the real state of the object. Information technology monitoring of technological processes in agriculture, and therefore the decision making systems for managing these processes on nowadays have imperfect for a number of reasons:

- lack of perfect database, including those in connection with large uncertainty quantitative and qualitative factors of production - the market situation, the state of agro-ecosystems, resource support and forecast data concerning the development crop or animal, and terms of the work, etc;

- the lack of intellectual component capable of efficiently and effectively carry out the support of decision rational -making;

- non- stationarity controlled by processes;

- the complexity of mathematical description of biological object (soil, plant, animal);

- very significant dependence on external conditions.

The main direction of improvement of the quality information technology is the intellectualization of information processing with application of methods intellectual analysis under the action of indeterminate factors, or in other words, the transition to the level of artificial intelligence.

The central element of the structure of the intellectual component system of automatic controlling the technological process (Figure 2) is a multidimensional neural network that, can be represented in interaction of the three main blocks:

- block acceptance and processing of information (sensor system); 
- block modulation (modeling system);

- block programming, starting and executive actions control (motor system).

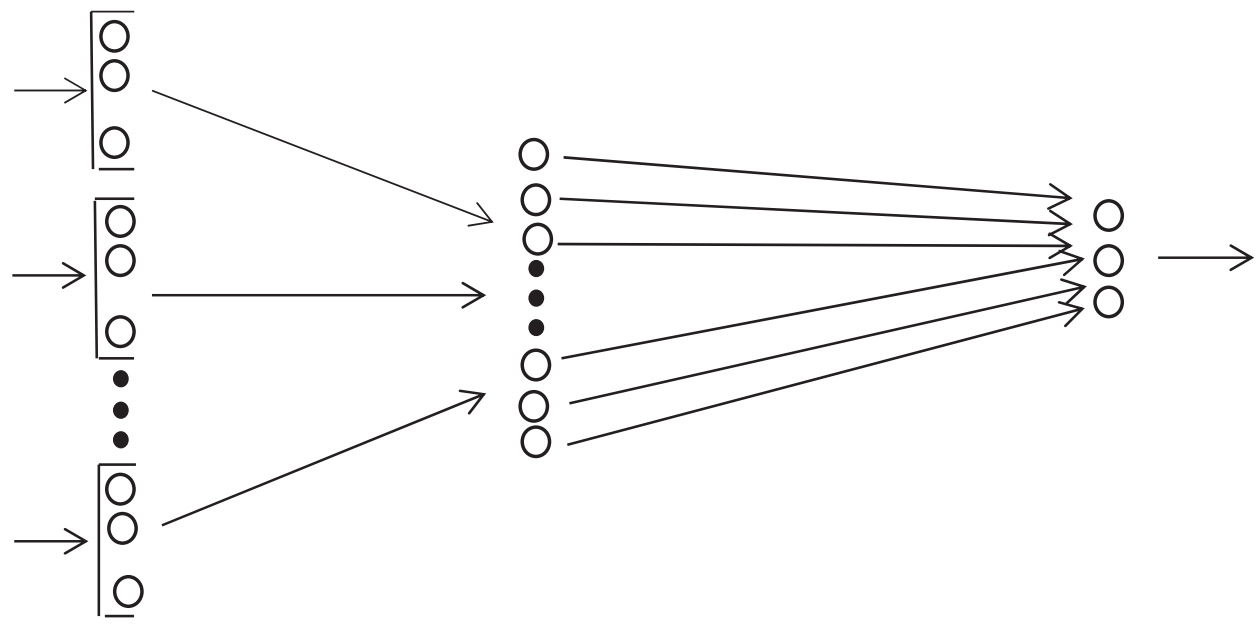

A B C

Fig. 2. Architecture of technical neural networks: A-sensor system; B-modeling system; C-motor system.

Sensory system starts to act when any factor acting on the corresponding sensitive element. The sensitive element forming an electrical impulse. This impulse comes to the analyzer - a multilevel system of hierarchical levels of construction. Every level - is set of elements whose outputs go to the next level. Interconnection between consecutive levels of analyzer built on the principle of convergence-divergence signs or parameters.

Modeling system is a machine which performs the function regulator of the active state, performs selective modulation and actualization of the priority of any function. The first source activation is the internal introductory. The second source activation is associated with the external factors.

Motor system carries out a synthesis of input signals of different modalities and importance of transforming it into a form of action.

Intellectual development of process control system envisages the combination a minimum of three professional areas of activity:

- system Engineer - to select the software and hardware tools for the project;

- expert on given subject area - understands the principles of problem solving, resolving known methods can provide inaccurate management information, to evaluate partial solutions;

- end user - determines the basic planning limitations - development continues until long as the user is not satisfied.

Known significant amount of software and hardware Instrumentation for constructing systems intelligent control by technological processes $[5,6,7]$ which can be successfully used for solution of the problem with the condition of certain adaptation.

End User for the technical systems of intelligent control by technological processes may be considered operator that controls the work of automated agricultural machines and equipment which sufficiently described in known works $[8,9,10]$.

Therefore, the key objective of creation of intellectual systems of technological processes of agricultural production at present is formalizing of renewable knowledge base on this subject area. One of the classic scheme of its construction is a method of gradual approximations. The basis is the creation of solutions, which compete with each other. Unsuccessful discarded, prospective survive and regenerated through the creation new solutions from parts of the successful "parents" (in technology - potential being increased or decreased).Errors leading to correction and increasing knowledge base. If a prototype is a very voluminous - from refusing it, but in the process, often creates a transparent version with much smaller number of rules. 
From a technical perspective, the basic functional unit of the structure of neural networks - neural element can be represented as an electronic device with a multiple positive and negative inputs, modeling input and one output with multiple lines. At the same amplitude and frequency of the signal may be regulated. Available from information neural elements are elements of novelty. Neural items that have a certain information are elements of identities (accordingly). Neural elements formation of inside information - elements that enhance or decrease the level of certain information to depending on the condition of internal systems, or the results of the function (action) that performed. Temporary memory temporary delay information which is necessary for analyzing and memorization it in the elements of novelty. By repeating its level of this information increases memorization up to the value specified threshold. Upon reaching the threshold value neural element temporary memory becomes neural element of identity and transferred to long-term memory. Long-term memory - all neural elements identity. The famous works in which describes the theory and practical realization of neural networks for a variety of problems $[4,5]$.

The real limiting factor intellectualization of modern agriculture is the absence of formal knowledge base (data). Consider, as an example, the possible algorithm formation of knowledge base that is essential for creation of IP management process of sowing grain.

Integral function of seed corn is the creation of the most favorable conditions for plant development through effective management workflows. The entire gamut of administrative actions, conditionally can be divided into direct and indirect actions. The direct actions include: availability of technical work process at preset time; depth, straightness, smooth operation and frequency of rotation of work; seeding rate (making) technological materials and others. Among the mediated by actions include: type of culture and its predecessor; preprocessing quality seeds; state and dynamics of changes soil of humidity and temperature taking into account prediction and others. And then, for example, the position of the dosing flap application of mineral fertilizers will be determined by calculated dose submission for this part of the field. The primary input information for calculating of real dose will be recommended norm of fertilizer for a specific culture. The signal responsible for that recommended norm clarifies at passage of through a group identity elements of different types of soil, then through the block of calculation recommended dose taking into account information about the actual content of the relevants chemical elements in the soil, then through the block of calculation recommended dose taking into account information regarding current and future provision of soil moist and goes to executive mechanism change of the position of the dosing flap.

That development and formalization of similar algorithms acceptance, processing, actualization of information and programming executive actions is today the most actual problem in the problem of intellectualization of technological processes of agricultural production.

\section{Conclusions.}

1. Reach a principal increase in the yield of agricultural production from a unit of area can be cultivated at introduction of new smart technologies.

2.The level of artificial intelligence in systems for technological processes of agricultural production can be limited use of theories calculations and logic.

3. The key objective of creation of intellectual systems of technological processes of agricultural production at present is formalizing of knowledge base.

\section{Bibliography}

1. Lyuger Dzhordzh F. Iskusstvennyiy intellekt: strategiya i metodyi resheniya slozhnyih problem. 4-e izdanie: Per. s ang. - M: izdatelskiy dom «Vilyams», 2003. - 864 s.

2. Galushkin A.I. Neyronnyie seti. Osnovyi teorii/A.I. Galushkin.- M.: Goryachaya liniya - Telekom, 2010.- $496 \mathrm{~s}$.

3. Kruglov V.V. Iskusstvennyie neyronnyie seti. Teoriya i praktika/V.V. Kruglov. - M.: Goryachaya liniya - Telekom, 2002. - $382 \mathrm{~s}$. 
4. Bodyanskiy E.V. Iskusstvennyie neyronnyie seti: arhitektura, obuchenie, primenenie./ E.V. Bodyanskiy, O.G. Rudenko.- M.: TELETEH, 2004.- 355s.

5. Terehov V.A. Neyrosetevyie sistemyi upravleniya/V.A. Terehov, D.V. Efimov, I.K. Tyukin. - M.: Vyisshaya shkola, 2002. - $184 \mathrm{~s}$.

6. Mironenko V.M. Razrabotka iskusstvenogo intelekta dlya diagnostiki parazitov na osnove neyronnoy seti Hemminga/V.M. Mironenko, E.A. Korchevskaya, S.S. Maenvskaya//Veterinarna blotehnologlya.-2013.- №22 - S.355-362.

7. Tyimochko V.O., Padyuka R.I. Identifikatsiya mashinno-traktornogo agregata s ispolzovaniem neyronnyih setey/ Nauchno-tehnicheskiy progress v selskohozyaystvennom proizvodstve: N34 materialyi Mezhdunar. nauch. tehn. konf. (Minsk, 22-23 oktyabrya 2014 g.). S. 233-238.

8. Myronenko V.G. Texnichni zasoby zabezpechennya yakosti vykonannya texnologichnyx procesiv u roslynnycztvi: Monografiya.-K.: Nacz. agrar. un-t, 2005.-202 s.

9. Brovarecz O.O. Informacijni texnologiyi ta texnichni zasoby novogo pokolinnya dlya monitoryngu j zabezpechennya yakosti vykonannya texnologichnyx procesiv pry vyroshhuvanni silskogospodarskyx kultur / O.O. Brovarecz // Nauchno-praktycheskyj zhurnal «Xranenye y pererabotka zerna». - 2013. - № 6 (171). - S. 37-42.

10. Bakuradze L.A., Lutsenko E.V. Teoriya, tehnologiya i praktika avtomatizatsii operativnogo upravleniya uborochno-zagotovitelnyimi kampaniyami v APK: Pod nauch. red. d.t.n., prof. V.I.Loyko. Monografiya (nauchnoe izdanie). - Krasnodar: KubGAU, 2008. - 550 s. 